\title{
Metabolic adaptations of deep-sea benthic foraminifera to seasonally varying food input
}

\author{
Peter Linke \\ Sonderforschungsbereich 313, Heinrich-Hecht-Platz 10, W-2300 Kiel 1, Germany
}

\begin{abstract}
ATP content and metabolic activity of benthic foraminifera were determined from deepsea sediments of the Norwegian-Greenland Sea. Metabolic activity was analysed by measurements of Electron Transport System (ETS) activity and heat production. This, combined with live observations, revealed 2 survival strategies. Rupertina stabilis, an obligate suspension feeder, is adapted to conditions in which it receives a steady input of particles throughout the year, enabling it to maintain a relatively high ATP content $\left(153 \pm 23 \mathrm{ng} \mathrm{ATP}\right.$ ind.$\left.^{-1}\right)$ with a reduced ATP turnover rate $\left(0.008 \mathrm{~s}^{-1}\right)$. In contrast Cribrostomoides subglobosum, Pyrgo rotalaria and Rhabdammina abyssorum undergo large (up to 10-fold) fluctuations in seasonal values of ATP and heat production, but retain a high, relatively constant ATP turnover rate (i.e. seconds). Such a rapid turnover allows these foraminifera to take quick advantage of sudden nutrient inputs; this state of readiness, however, is maintained at the cost of the protoplasm, which benthic foraminifera are apparently capable of metabolizing in times of starvation. $C$. subglobosum and $P$. rotalaria responded to several sedimentation events with an increase in ETS activity; single cells sometimes showed extremely high ATP values (50- to 100 -fold increase), reflecting an individual physiological response to food input to the deep-sea.
\end{abstract}

\section{INTRODUCTION}

The abundance of benthic foraminifera in the deepsea is reported to be greater than that of any other eukaryotic taxon (Tietjen 1971, Hessler 1974, Smith et al. 1976, Tendal \& Hessler 1977, Snider et al. 1984, Gooday 1986, 1990, Alongi \& Pichon 1988, Altenbach \& Sarnthein 1989, Gage \& Tyler 1991). In the deep-sea of the Arctic oceans they account for a major part of the benthic biomass (Fetter 1973, Basov \& Khusid 1983). New techniques are already being used to measure the biomass of benthic foraminifera directly by organic carbon (Altenbach 1987) and adenosine-5'triphosphate (ATP) assays (DeLaca 1986). Little information, however, is available on their metabolism. Since protozoa have a high growth potential they may be expected to be of importance in terms of turnover rates in biotopes where they are especially abundant.

The Norwegian-Greenland Sea is influenced by different currents and water masses, varying processes which may be expected to control particle sedimentation. The Norwegian Atlantic Current imports warm
Atlantic water; on the Norwegian Shelf the Norwegian Coastal Current flows with less saline water to the Northeast; the East Greenland Current brings in a cold water mass from the Arctic (Fig. 1). Mackensen and co-authors (1985) conducted the first large-scale studies on foraminiferal distribution patterns in the Norwegian-Greenland Sea and concluded that the oxygen content of the bottom water and the organic carbon load of the sediment are among the environmental parameters that influence foraminiferal assemblages. The following investigations were guided by the growing realization that adaptation to nutritional conditions rather than water mass properties or physical parameters alone controls foraminiferal distribution (Altenbach 1985, Lutze et al. 1986, Mackensen 1987, Linke 1989, Lutze \& Thiel 1989, Thies 1991, Gooday et al. 1992).

It is already evident that the response by a bathyal benthic community to a pulse of natural organic matter occurs within days (Graf 1989). A direct response of shallow-water benthic foraminifera to food input has been documented in the Kiel Bight, Baltic Sea 


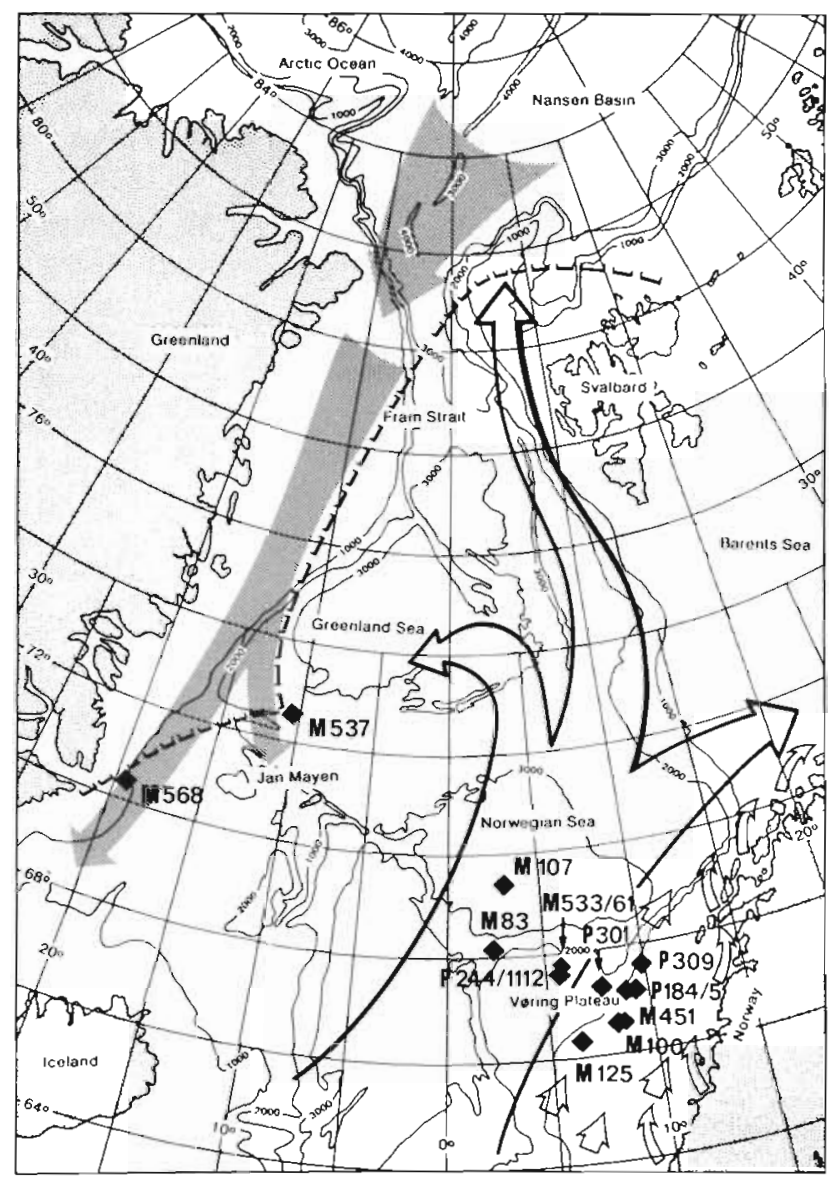

Fig. 1 Stations in the Norwegian-Greenland Sea with a scheme of the oceanographic currents and the boundary between ice-covered and relatively warm Atlantic water masses in the North Atlantic. $\sim-$. September ice boundary; small white arrows Norwegran Coastal Current; large white arrow Norwegian Atlantic Current, hatched arrow East Greenland Current

(Altenbach 1985). After the sedimentation of the spring phytoplankton bloom increased growth rates and subsequent reproduction were found. In upwelling areas a direct correlation between primary production in the euphotic zone and biomass and species composition of benthic foraminifera has been shown (Lutze et al 1986) Gooday (1988) described a rapid response of abyssal benthic foraminifera to freshly sedimented phytodetritus.

The present study attempts to show that benthic forammifera are capable of competıng in the struggle for the limited food supply that characterizes most deep-sea environments and have developed morphological and physiological adaptations to survive in this extreme habitat In this paper, clata on the energy metabolism of foraminifera from sediments influenced by the 3 different hydrographic and sedimentation regimes mentioned above are presented.

\section{MATERIAL AND METHODS}

Foraminiferal data from 6 expeditions (1985 to 1988) and 15 stations (Table 1, Fig. 1) between the Norwegian shelf and the East Greenland shelf are presented. Luve observations were conducted immediately upon recovery of large box corers $(50 \times 50 \mathrm{~cm}$ surface area) in a specially equiped 'biocontainer' on deck of RV 'Meteor', using a binocular microscope (Wild, $\times 650$ ). This microscope can be placed directly above the sample cores by means of a flexible arm, eliminating the need to handle the sample prior to microscopy. Sediment cores were taken with a multiple corer (modified from Barnett et al. 1984) using plexiglass tubes with a $10 \mathrm{~cm}$ inner diameter or as subcores from the large box corer. The top and the bottom of each sediment core was stoppered with 'Delrin' and the cores were kept in a temperature-controlled refrigerator close to in situ temperature $\left(-0.7^{\circ} \mathrm{C}\right)$. The upper centimeter of each sediment core was removed and gently washed with precooled seawater on a plastic sleve with a mesh size of $250 \mu \mathrm{m}$. The remains in the sieve were transferred into glass petri dishes and living foraminufera were picked out with forceps under a dissection microscope (Wild, $\times 8$ ). The foraminifera were gently cleaned of adhering detritus. Samples were kept at in situ temperature by means of a cooling stage built on the microscope table (Linke 1989). Live individuals were identified according the following critena: the presence of protoplasm visible through the test, plasma threads and/or a plug of accumulated detrital matter, built by pseudopodial activity around the apertural region. Maximum length of most foraminifera isolated for measurements of their energy metabolism was determined, but will not be listed in this paper, as there was no significant relationship found. Determinations of each species' test volume might give a better correlation, but will still imply a significant source of error, since some species have thick walls, numerous small chambers and protoplasm which does not occupy the entire internal test volume. Altenbach (1987) estimated that between 10 to $62.2 \%$ of the test interlor of Rhabdammina abyssorum, a species also examined in this study, was filled by protoplasm.

For ATP extraction single foraminifera were transferred into test tubes and rinsed to the tube bottom with 1 to $2 \mathrm{ml}$ of boiling $0.02 \mathrm{M}$ Tris buffer $(\mathrm{pH} 7.8)$. Tubes were held in an Erlenmeyer flask with boiling water, which was heated by a sand bath. The tests of the foraminifera were crushed with a glass rod to optimize the extraction efficiency and to shorten the extraction time to $30 \mathrm{~s}$. Extracted samples were stored at $-20^{\circ} \mathrm{C}$ untıl analysis several weeks later. The real dilution of the samples was determined by weighing 
Table 1. Cruises, locations and depth of stations mentioned in the text

\begin{tabular}{|c|c|c|c|c|c|}
\hline Cruise-Leg & $\sin$ & Date & Latitude $(\mathrm{N})$ & Longitude $(E)$ & Depth $(\mathrm{m})$ \\
\hline Poseidon 119 & $\begin{array}{l}\text { P301 } \\
\text { P309 }\end{array}$ & $\begin{array}{l}25 \text { Jul } 85 \\
26 \text { Jul } 85\end{array}$ & $\begin{array}{l}67^{\circ} 04.36^{\prime} \\
67^{\circ} 45.43^{\prime}\end{array}$ & $\begin{array}{l}7^{\circ} 29.04^{\prime} \\
9^{\circ} 46.41^{\prime}\end{array}$ & $\begin{array}{r}1252 \\
614\end{array}$ \\
\hline Poseidon 128-2 & P244 & 26 May 86 & $67^{\circ} 39.09^{\prime}$ & $5^{\circ} 48.41^{\prime}$ & 1430 \\
\hline Meteor 2-1 & $\begin{array}{l}\text { M61 } \\
\text { M83 }\end{array}$ & $\begin{array}{l}23 \text { Jun } 86 \\
30 \text { Jun } 86\end{array}$ & $\begin{array}{l}67^{\circ} 43.2^{\prime} \\
68^{\circ} 14.4^{\prime}\end{array}$ & $\begin{array}{l}5^{\circ} 53.8^{\prime} \\
2^{\circ} 33.1^{\prime}\end{array}$ & $\begin{array}{l}1245 \\
2398\end{array}$ \\
\hline Meteor 2-2 & $\begin{array}{l}\text { M100 } \\
\text { M107 } \\
\text { M125 }\end{array}$ & $\begin{array}{l}04 \text { Jul } 86 \\
05 \text { Jul } 86 \\
13 \text { Jul } 86\end{array}$ & $\begin{array}{l}66^{\circ} 49.4^{\prime} \\
69^{\circ} 30.2^{\prime} \\
66^{\circ} 20.7^{\prime}\end{array}$ & $\begin{array}{l}7^{\circ} 57.3^{\prime} \\
2^{\circ} 59.5^{\prime} \\
6^{\circ} 16.8^{\prime}\end{array}$ & $\begin{array}{r}606 \\
3276 \\
607\end{array}$ \\
\hline Poseidon 137 & $\begin{array}{l}\text { P184 } \\
\text { P185 }\end{array}$ & $\begin{array}{l}13 \mathrm{Feb} 87 \\
13 \mathrm{Feb} 87\end{array}$ & $\begin{array}{l}67^{\circ} 18.81^{\prime} \\
67^{\circ} 15.77^{\prime}\end{array}$ & $\begin{array}{l}8^{\circ} 37.99^{\prime} \\
8^{\circ} 43.38^{\prime}\end{array}$ & $\begin{array}{l}804 \\
601\end{array}$ \\
\hline Poseidon 141-2 & P1112 & $22 \operatorname{Oct} 87$ & $67^{\circ} 39.07^{\prime}$ & $5^{\circ} 46.92^{\prime}$ & 1419 \\
\hline Meteor 7-3 & M451 & 10 Aug 88 & $66^{\circ} 53.1^{\prime}$ & $8^{\circ} 02.2^{\prime}$ & 614 \\
\hline Meteor 7-4 & $\begin{array}{l}\text { M533 } \\
\text { M537 }\end{array}$ & $\begin{array}{l}30 \text { Aug } 88 \\
02 \text { Sep } 88\end{array}$ & $\begin{array}{l}67^{\circ} 44.1^{\prime} \\
72^{\circ} 35.6^{\prime}\end{array}$ & $\begin{array}{c}5^{\circ} 55.6^{\prime} \\
10^{\circ} 29.1^{\prime} \mathrm{W}\end{array}$ & $\begin{array}{l}1243 \\
2183\end{array}$ \\
\hline Meteor 7-5 & M568 & 15 Sep 88 & $70^{\circ} 23.6^{\prime}$ & $19^{\circ} 19.9^{\prime} \mathrm{W}$ & 397 \\
\hline
\end{tabular}

the test tubes with and without the extracts. ATP was measured according to the method of Witzel (1979) using a JRB ATP-photometer. ATP contribution from bacteria attached to the test exterior has been estimated to be on the order of $1 \%$ of the total ATP content (Bernhard 1989). This is in accordance with the estimate of Linke (1989), who calculated the ATP content of a $1 \mu \mathrm{m}$ thick layer of bacteria covering an idealized foraminiferal test by using a carbon: ATP conversion factor of $250: 1$.

Direct microcalorimetry is a method for measuring smallest heat flows produced by the metabolism of living organisms (Pamamat 1978, Shick 1981, Gnaiger 1983, Hammen 1983) independant of the type of metabolism. For aerobic metabolism the oxycaloric coefficient (20.1 $\mathrm{J}=1 \mathrm{ml} \mathrm{O}_{2}$ ) of Ivlev (1934) can be used to calculate the oxygen consumption of foraminifera from heat production measurements. Furthermore these values can be compared to the potential oxygen consumption obtained by the ETS-method (described below).

Heat production of foraminifera was measured on 'Meteor' Cruise M2 in a multicalorimeter (Graf et al. 1988) providing a maximum sample size of about $70 \mathrm{~cm}^{3}$. Depending on the size and the availability of sufficient numbers of living foraminifera up to 200 individuals were placed in the seawater-containing stainless steel chambers. All the other heat production measurements were conducted in a double twin calorimeter (described in Graf 1987). In this instrument 2 commercial LKB batch calorimeters (Type 10700-1 \& -2) were modified and encased in a stainless steel container submerged in a temperature-controlled water bath. Due to the smaller sample size $\left(4 \mathrm{~cm}^{3}\right)$ up to 95 foraminifera were placed in these chambers. Both calorimeters were run at $-0.5^{\circ} \mathrm{C}$. After closing the chambers they were precooled in a refrigerator to shorten the equilibration time. Thermograms were linear $4 \mathrm{~h}$ after starting a measurement; heat flow was integrated for the subsequent $5 \mathrm{~h}$. After each measurement a control using only seawater was monitored in the same way as a sample. Subtraction of the baseline value from the corresponding sample value eliminated equilibration and contamination effects due to bacteria in the water. As the main heat-releasing process during metabolism is the production and dephosphorylation of ATP (Himms-Hagen 1976) and as the contribution of ATP from bacteria attached to the test exterior has been estimated to be on the order of $1 \%$ of the total ATP content (Bernhard 1989), the heat production attributable to these associated organisms and not the foraminifera should be rather small, but cannot be excluded. Due to the rather small size of most foraminifera examined in this study it was not possible to measure the heat production of single foraminifera; a high variability in the heat production of single individuals has to be expected. Therefore the same foraminifera used in the microcalorimeter were taken for ATP and ETS measurements to obtain comparability between measurements and to provide the basis for further calculations.

As heat production measurements contain a time factor $\left(1 \mathrm{~W}=1 \mathrm{~J} \mathrm{~s}^{-1}\right)$, combination with ATP-measurements provides an additional activity parameter (ATP turnover rate), which gives information about the dynamics of metabolic processes in the cell. Gnaiger (1980) gave the caloric equivalents of ATP turnover for various types of metabolism. ATP turnover rates were calculated assuming a heat release of $77 \mathrm{~kJ}$ mole ${ }^{-1}$ ATP for aerobic metabolism.

ETS activity was measured according to the methods of Christensen \& Packard (1977) and Kenner \& Ahmed (1975) modified by Graf \& Bengtsson (1984). Between 
10 and 20 foraminifera were ground for $60 \mathrm{~s}$ in $3 \mathrm{ml}$ cold $0.1 \mathrm{M}$ phosphate buffer $(\mathrm{pH} 8.2)$ in a Potter tissue grinder with a Teflon pestle placed in an ice bath to prevent temperature increase above $15^{\circ} \mathrm{C}$. Samples were incubated at a constant temperature in a water bath. Incubation temperatures varied between -0.5 and $23.5^{\circ} \mathrm{C}$; the samples were correspondingly incubated between 10 and $60 \mathrm{~min}$. The reaction was stopped with $1 \mathrm{ml}$ of $1.0 \mathrm{M} \mathrm{H}_{3} \mathrm{PO}_{4}$ in $4 \%$ formaldehyde solution (1:1 proportion). After centrifuging for $10 \mathrm{~min}$ at $3500 \mathrm{rpm}$, sample absorbance was measured at $492 \mathrm{~nm}$. As controls, to determine nonenzymatic reduction of the tetrazolium dye (INT), $1 \mathrm{ml}$ of each sample was initially treated with the stopper solution and incubated in the same way as the experimental sample. Another control to check the different buffers was carried out by incubating $1 \mathrm{ml}$ of homogenisation buffer in place of the homogenate. All ETS-values were calculated per individual with the Arrhenius formula to the in situ temperature.

Statistics and significance ( $t$ - and $F_{\text {-) }}$ ) tests were used according to Cavalli-Sforza (1972).

\section{RESULTS}

\section{Live observations}

At the stations on the Norwegian continental margin a biotope of suspension-feeding benthic animals occurred, extending from the Vøring Plateau northwards for at least 200 to $300 \mathrm{~km}$. In a distinct depth range between 600 and $800 \mathrm{~m}$ the suspension feeding benthic foraminifer Rupertina stabilis occurs in high population densities (Lutze \& Altenbach 1988). The distribution of this species is extremely patchy with densities reaching up to 100 ind. $10 \mathrm{~cm}^{-2}$ on exposed rocks.

Attached to hard substrates, and obviously preferring elevated positions, this species is exposed to the bottom currents. Around the apertural region Rupertina stabilis erects sponge spicules which allows it to spread its fragile adhesive protoplasm into the water as a pseudopodial network (Fig. 2A). Another benthic foraminifer of this biotope, Rhabdammina abyssorum, lacks the morphological adaptations of Rupertina stabilis. Rhabdammina abyssorum was mostly found lying on the sediment surface, accumulating detrital matter by pseudopodial activity (Fig. 2B). In 1 case Rhabdammina abyssorum and Rupertina stabilis were observed together on the inner wall of a crustacean burrow extending their pseudopodia into the respiratory current of the megafaunal inhabitant (Fig, 2C). Rhabdammina abyssorum was also found at Stn M568 on the East Greenland continental margin.

On the Vøring Plateau and in the deep-sea basins of the Norwegian Greenland Sea only 4 species make up more than $90 \%$ of the foraminifera in the $>250 \mu \mathrm{m}$ fraction: Cribrostomoides subglobosum, Reophax scorpiurus, Pyrgo rotalaria and Cibicidoides wuellerstorfi (Lutze \& Salomon 1987). Cribrostomoides subglobosum (Fig. 2D) and $P$. rotalaria (Fig. 2E) were mostly found living on the sediment surface or the top centimeter of the sediment. Those scavenging at the sediment surface develop long whiplike plasma threads to draw even large particles towards their aperture (Fig. 2F). Those individuals which were found in the sediment showed a 'plug' of accumulated detrital matter, built by pseudopodial activity around the apertural region.

\section{Energy metabolism measurements}

Norwegian continental margin. The suspension feeder Rupertina stabilis showed the highest mean ATP content per individual of all foraminifera studied. It maintained an ATP content of $153 \pm 23 \mathrm{ng}$ ind $^{-1}$ (overall mean of data; $\mathrm{n}=36$ ) and showed no changes (at the $5 \%$ significance level) during February 1987. July 1986 and August 1988. In contrast, Rhabdammina abyssorum had only $23.1 \pm 2.9 \mathrm{ng}$ ATP ind. ${ }^{-1}$ (overall mean of data; $n=53$ ), though this species had a much larger test (mean test length $18.5 \mathrm{~mm}$ ) than Rupertina stabilis (mean test length $1.1 \mathrm{~mm}$ ). Furthermore Rhabdammina abyssorum had 10-fold lower ATP values in February 1987 than in July 1985 (Fig. 3). The mean ATP values of Rhabdammina abyssorum from the East Greenland Current (Stn M568) in September 1988 were in the same order of magnitude as those of the same species living on the Norwegian continental margin.

Replicate heat production measurements of Rhabdammina abyssorum conducted with the multicalorimeter $\left(27.6 \pm 7.3 \times 10^{-7} \mathrm{~J} \mathrm{~s}^{-1}\right.$ ind $^{-1} ; \mathrm{n}=6$; in July 1986 ,

Fig. 2. Living deep-sea benthic foraminifera. (A) Rupertina stabilis attached to a hydrozoan stalk growing on a stone. Preferring elevated positions $R$. stabilis errects sponge spicules at its apertural region to support and expose its fragile adhesive pseudopodia into bottom currents catching suspended material (scale bar $=1 \mathrm{~mm}$ ). (B) Rhabdammina abyssorum with plugs of accumulated detrital matter at its apertures (scale bar $=5 \mathrm{~mm}$ ). (C) View into a crustacean burrow with (a) Rupertina stabilis and (b) Rhabdammina abyssorum at its wall, extending their pseudopodia into the respiratory current of the megafaunal inhabitant (scale bar $=5 \mathrm{~mm}$ ). (D) Cribrostomoides subglobosum and (E) Pyrgo rotalaria develop long whiplike plasma threads for scavenging the sediment surface. (F) Cribrostomoides subglobosum with a large particle at its aperture. (D to F, scale bar $=200 \mu \mathrm{m}$ ) 

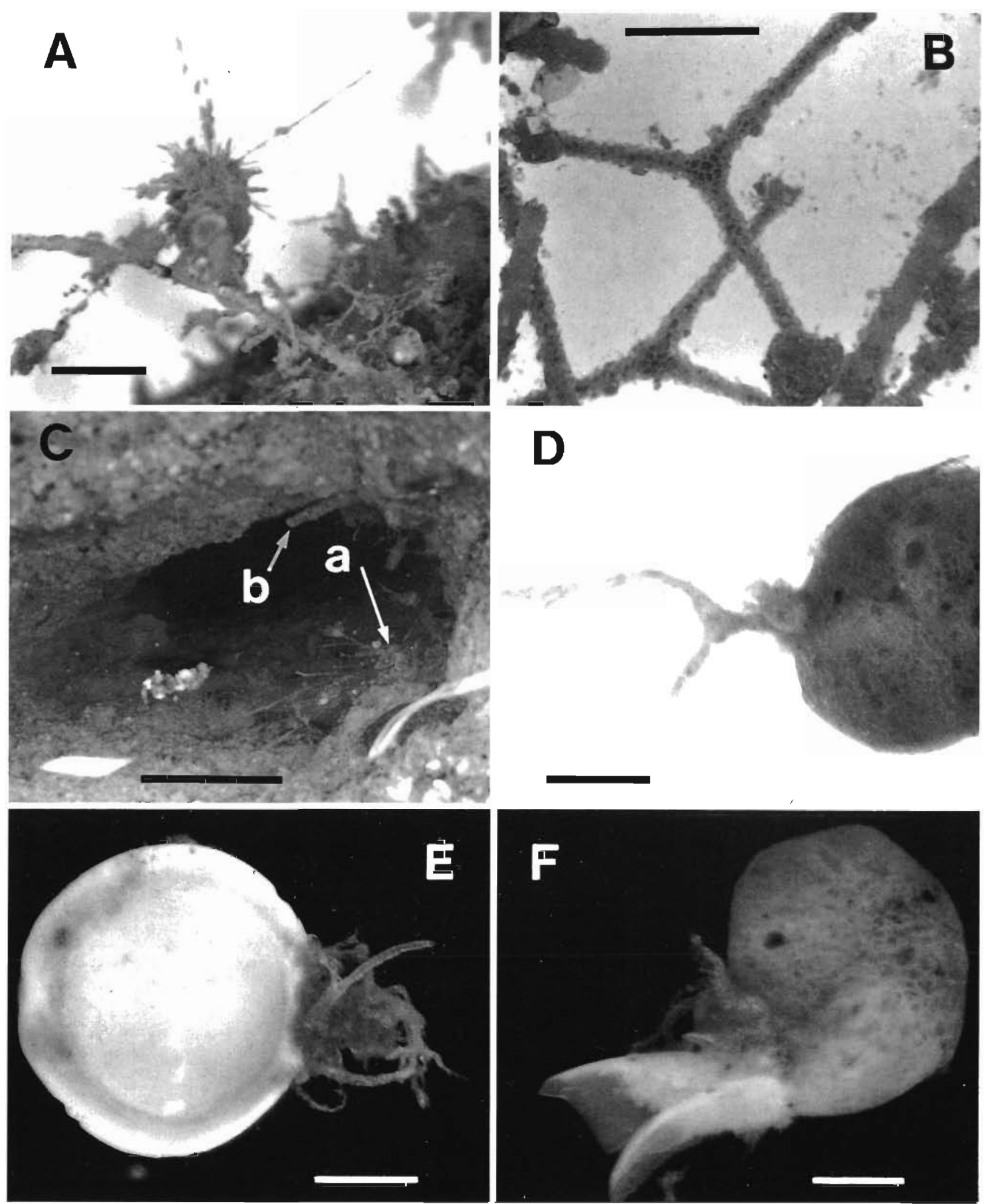


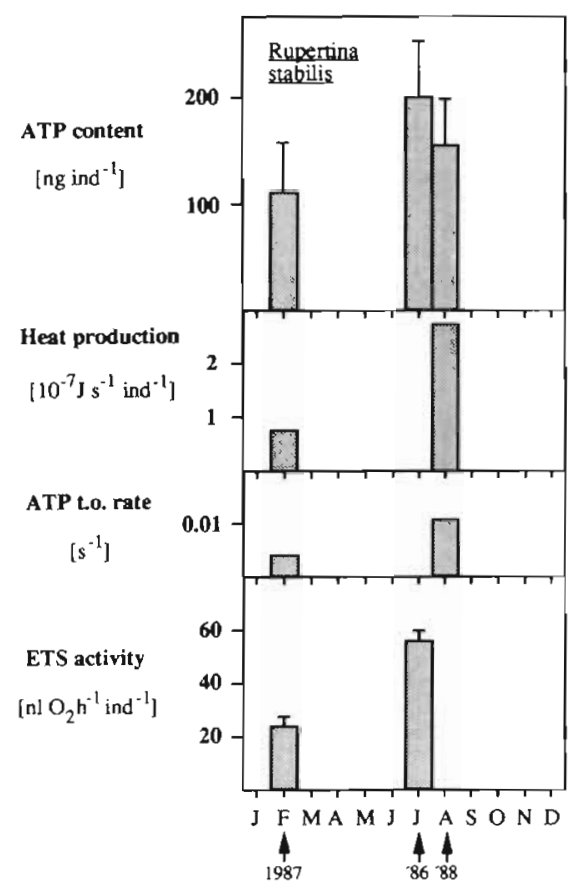

Table 2, not shown in Fig. 3) agreed well with the value obtained with the double twin calorimeter $\left(31.3 \times 10^{-7} \mathrm{~J} \mathrm{~s}^{-1}\right.$ ind ${ }^{-1}$, in July 1985, Fig. 3). These high values were much higher than those for Rupertina stabilis $\left(2.75 \times 10^{-7} \mathrm{~J} \mathrm{~s}^{-1}\right.$ ind.- ${ }^{-1}$, in August 1988). For Rhabdammina abyssorum heat production measurements, like ATP values, were reduced by a factor of 10 in February 1987 compared to in July 1985/86. This is reflected in the calculated ATP turnover rates, which were identical for these 2 data sets $\left(0.63 \mathrm{~s}^{-1}\right)$. In comparison Rupertina stabilis living in the same biotope as Rhabdammina abyssorum showed only a factor of 3.7 in the seasonal variation of heat production between February 1987 and July 1986. The ATP turnover rates obtained for Rupertina stabilis were considerably lower, with the lowest value in February 1987 $\left(0.004 \mathrm{~s}^{-1}\right)$, and an elevated turnover rate in August $1988\left(0.011 \mathrm{~s}^{-1}\right)$.

In the case of Rupertina stabilis the oxygen consumption calculated from heat production in February 1987 was only half of the potential value obtained by the ETS measurements, whereas in August 1988 both methods gave similar results (Table 2); the metabolic potential was almost entirely exploited. Comparing the 2 sets of oxygen consumption rates of Rhabdammina abyssorum a discrepancy was found. The potential oxygen consumption was considerably lower than the 'actual' value calculated from heat production.

Voring Plateau and deep-sea basins. The ATP content of Pyrgo rotalaria has a high variability. Against background values of 0.3 to $0.5 \mathrm{ng}$ ATP ind. ${ }^{-1}$ single, extremely high ATP contents were found in July 1985

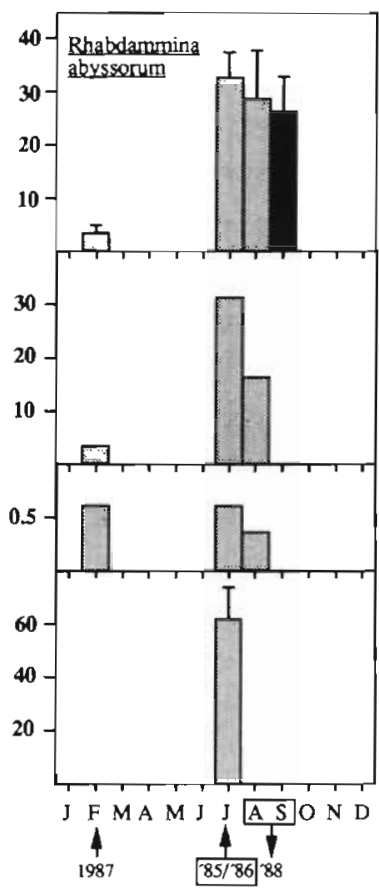

Fig. 3. Rupertina stabilis, Rhabdammina abyssorum. Energy metabolism of foraminifera from the Norwegian and the East Greenland (black bars) continental margin. Mean values \pm SD are given for parallel measurements. Note the different scales in the histograms except for ETS activity)

(11.7 and 77.4 ng ATP ind ${ }^{-1}$; $\mathrm{n}=2$; Stn P304, not shown in Table 2 or Fig. 4) and July 1986 (34.7 ng ATP ind. ${ }^{-1}$; Stn M107). Individuals from Stn M537 in the East Greenland Current had an elevated mean ATP content of $1.64 \pm 0.22 \mathrm{ng}$ ind $^{-1}$. Nevertheless the mean ATP content, heat production and potential oxygen consumption showed a distinct pattern of high values in July 1986 and low ones in October 1987 (Fig. 4). The high heat production values of $P$. rotalaria from Stn M107 in the Lofoten Basin $\left(32.5 \times 10^{-7} \mathrm{~J} \mathrm{~s}^{-1}\right.$ ind.-1 in July 1986) are similar to the heat production obtained for Rhabdammina abyssorum from the Norwegian continental margin.

The most common species on the Vøring Plateau, Cribrostomoides subglobosum, showed a variability in ATP content comparable to Pyrgo rotalaria with increased values in June 1986 and August 1988. Again the highest ATP content and potential oxygen consumption was measured with individuals from Stn M537 in the East Greenland Current (Fig. 4).

In general, the calculated ATP turnover rates of Pyrgo rotalaria and Cribrostomoides subglobosum were in the range known for bacteria (Table 2), much higher than the values obtained for the 2 species from the Norwegian Continental margin.

Comparing the 2 sets of oxygen consumption rates calculated from heat production and ETS measurements for Pyrgo rotalaria and Cribrostomoides subglobosum a discrepancy was found (Table 2). Like for Rhabdammina abyssorum the potential oxygen consumption was considerably lower than the 'actual' value calculated from heat production. Therefore incu- 


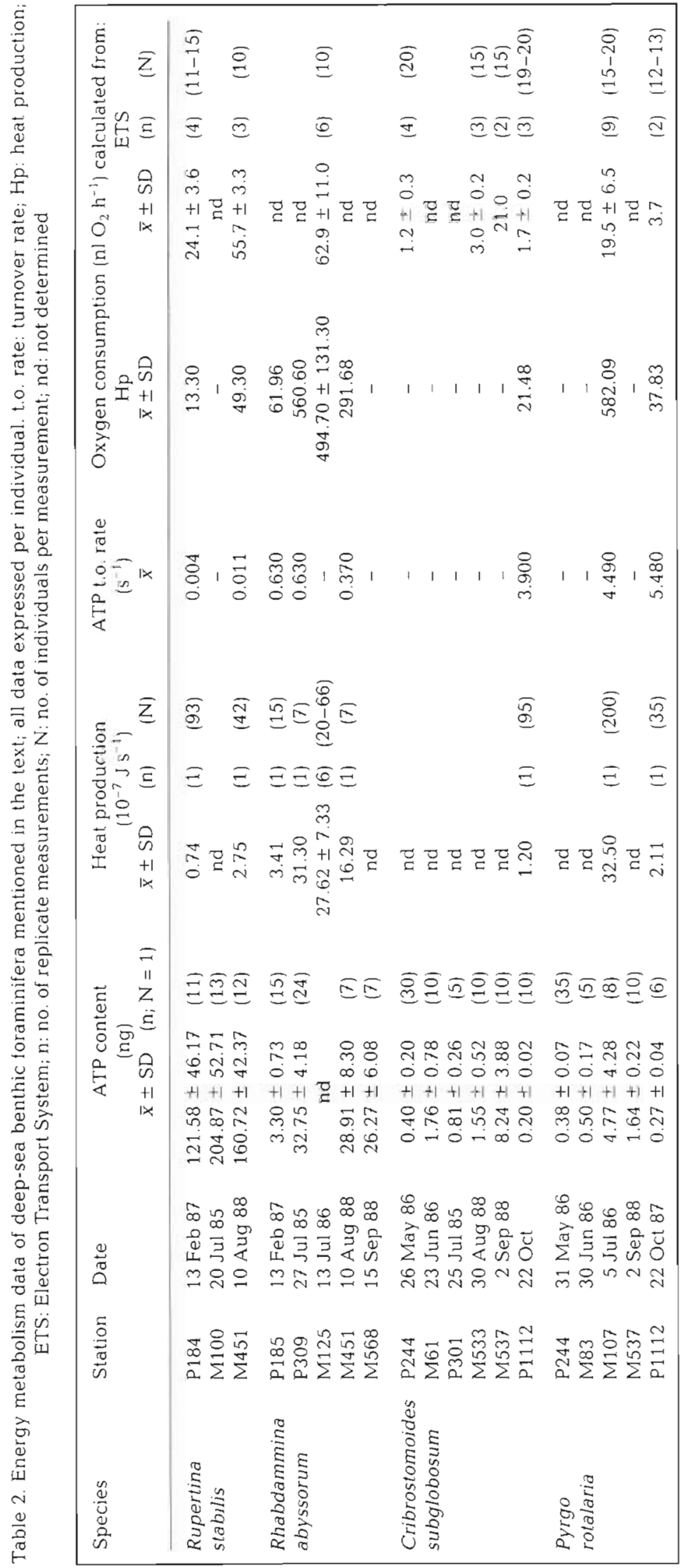




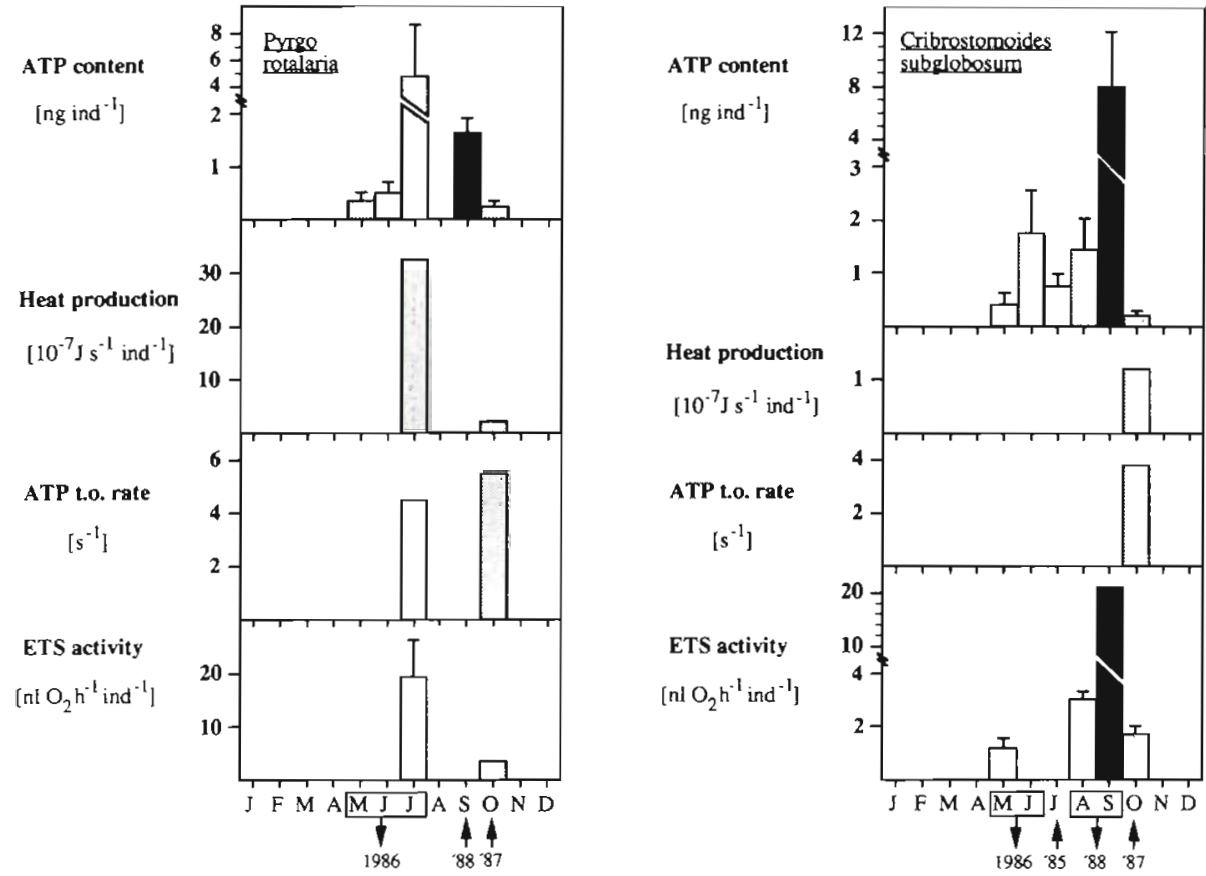

Fig. 4. Pyrgo rotalaria, Cribrostomoides subglobosum. Energy metabolism of foraminifera from the Voring Plateau, the deep. sea basins of the Norwegian Sea and the Greenland Sea (black bars). Mean values $\pm \mathrm{SD}$ are given for parallel measurements. Note the different scales on yaxes (except for ATP turnover rate) and varying linear scaling on vertical axes for ATP content and ETS activity bation experiments were conducted with $P$. rotalaria (from Stn M107) at in situ temperature. The obtained potential values $\left(30.1 \pm 12.0 \mathrm{nl} \mathrm{O}_{2} \mathrm{~h}^{-1}\right.$ ind. $\left.^{-1} ; \mathrm{n}=3\right)$ were higher but not significantly different at the $5 \%$ level from those values $\left(14.3 \pm 7.5 \mathrm{nl} \mathrm{O} \mathrm{O}^{-1}\right.$ ind. ${ }^{-1}$; $\mathrm{n}=6$ ), which were only calculated with the Arrhenius formula to the in situ temperature. This might be an indication that the enzymes of the electron transport chains of those foraminifera living in greater water depths are adapted to lower temperatures.

\section{DISCUSSION}

\section{Seasonality in food supply}

In boreal or arctic seas the particle flux from the pelagial to the benthos is dominated by short, but intensive sedimentation events. This is especially true for the organic fraction originating from pelagic production which forms the primary food source to the benthos. Even in great water depths these fluctuations in particle flux cause periods of short-term excess food supply and long periods of starvation (Billett et al. 1983).

In shallow water systems like the Kiel Bight (Baltic Sea) such sedimentation events elicit a short-term (2 to $4 \mathrm{wk}$ ) increased benthic activity, mainly of bacteria and protozoa (Graf et al, 1983, Meyer-Reil 1983, Graf 1987). Bacteria respond with accelerated biomass production and subsequent cell division (Meyer-Reil 1984, 1986, Meyer-Reil \& Graf 1986). Four weeks after sedimentation of the spring phytoplankton bloom in this area the biomass of benthic foraminifera had increased significantly (Altenbach 1985, Altenbach \& Sarnthein 1989).

Freshly sedimented phytodetritus colonized by benthic foraminifera (Gooday 1988) and flagellates (Lochte \& Turley 1988, Turley et al. 1988) has been reported from deep-sea areas in the NE Atlantic (Thiel et al. 1990). This kind of sedimentation gives a strong seasonal impulse to the benthos, which should influence the life strategies of single species as well as the turnover rates of the whole benthic community (Gooday \& Lambshead 1989, Gooday \& Turley 1990).

The study of these processes and reactions to seasonality in the deep-sea involve many limitations as it is virtually impossible to obtain the ship time necessary to sample at different seasons during the same year. Most results have to be pieced together from observations made during different years, raising the possibility that the observed pattern could have arisen, in part, from interannual rather than seasonal variation.

On the Vøring Plateau, Graf (1989) found a response of the deep-sea benthos to a food pulse on a time-scale of days. Heeger (1990) investigated the immediate feeding response of benthic foraminifera to several sedimentation events on the Voring Plateau and under the East Greenland Current by using Transmission Electron Microscopy (TEM). After such events the food vacuoles of the sediment-dwelling species contained fresh plankton material, whereas during times of low food input the foraminifera ingested more strongly degraded material. In contrast, elevated epibenthic 
foraminifera receive and ingest fresher food particles than sediment-dwelling species (Heeger 1990).

The metabolic measurements presented in this study of 2 sediment-dwelling species (Cribrostomoides subglobosum and Pyrgo rotalaria) and 1 which is sometimes capable of suspension feeding (Rhabdammina abyssorum) demonstrate strong seasonal fluctuations and suggest metabolic adaptations to fluctuations in food supply. Most sediment bacteria, for example. adapt to low nutrient levels (Morita 1979) by reducing their metabolism in times of nutrient deficiency (see Henis 1987 for a review of the survival and dormancy of microorganisms).

DeLaca (1986) emphasized that in measuring the biomass of benthic rhizopods, estimates based on ATP analysis refer only to protoplasm biomass. The extreme fluctuations in individual ATP content presented in this study indicate that the inner volume of the foraminiferal test is not always entirely filled with plasma. Since great care was taken to ensure immediate homogenization of the specimens, insufficient extraction efficiency may be excluded. Substantial variations in the plasma content of foraminiferal tests are already known (Nuglisch 1985, Altenbach 1987) and have been attributed to ecological effects. Observations on Elphidium crispum (Myers 1942) indicate a seasonal effect on protoplasm content; up to February the protoplasm was retracted and it was not until March that the younger chambers of the tests were refilled.

Benthic foraminifera are apparently capable of metabolizing their own protoplasm in times of starvation, i.e. the protoplasm content of the test is influenced by nutritional status. TEM micrographs of foraminifera show a strong vacuolization of the protoplasma and a degradation of reserve substances (lipid vesicles) in periods of low food input (Heeger 1990). In contrast to this, the protoplasm of species adapted to a steady food input is denser, less vacuolized and contains stored lipid vesicles, which amount to more than $50 \%$ of the protoplasm volume in the older chambers. Analyses of the hydrolytic activity of individual foraminifera have also demonstrated large variations of enzymatic activity, which depend on the physiological state of the organisms (Köster et al, 1991).

Another explanation for fluctuations in ATP content is a dephosphorylation of ATP to ADP and AMP in periods of starvation. This would be energetically economical, avoiding the need to maintain a high ATP level. Additionally, maintaining a high AMP level allows the cell to retain the ability to respond rapidly to events like sudden pulses of food. Indications for such a physiological 'awakening' reaction are reported by Graf \& Linke (1992) from a feeding experiment. Freshly sampled Cribrostomoides subglobosum proved to have extremely low ATP : AMP ratios. The simulated food pulse increased the ATP content to a factor of 3 within $4 \mathrm{~d}$, most likely by phosphorylating AMP to ATP. After this awakening reaction the foraminifera increased ATP up to a factor of 10 , probably as a production of biomass (Graf \& Linke 1992). Further experiments have to be carried out to determine whether this is a general feature of deep-sea metabolism or merely an artifact of decompression.

\section{Norwegian continental margin}

On the continental margin a closer coupling of pelagic production and benthic processes can be assumed to occur than in the deep-sea due to shallower water depths. In the Norwegian Coastal Current primary production amounts to 90 to $120 \mathrm{~g}$ org. C m m $^{-2}$ $\mathrm{yr}^{-1}$. Most of this is produced during the spring bloom (April to June) at an elevated production rate of $4.5 \mathrm{~g}$ org. C m $\mathrm{m}^{-2} \mathrm{~d}^{-1}$ (Rey 1981). Thus the supply of fresh organic material in the biotope of Rupertina stabilis and Rhabdammina abyssorum is seasonal (Lutze \& Altenbach 1988). On the other hand this slope position is known for shifting water masses, where benthic enrichment by vertically and horizontally transported particles is thought to take place. Together with cold winter water cascades (Rumohr 1992) and relatively strong bottom currents this biotope is influenced by intensive lateral advection that favours suspension feeding.

The ATP content of Rupertina stabilis, a highly adapted suspension feeding foraminifer, showed only slight seasonal fluctuations in comparison with Rhabdammina abyssorum. On the other hand a seasonal doubling in values of heat production, oxygen consumption and ATP turnover rate occurred in this species. This indicates that Rupertina stabilis is capable of maintaining a high and relatively constant protoplasm content throughout the year. In periods of reduced food quality between the main sedimentation events it reduces only the ATP turnover rate, which even in summer is considerably lower than that of the other species. This is supported by a comparison between 'potential' and 'real' oxygen consumption values. In August both values coincide, indicating that the metabolic potential was almost entirely exploited, whereas in February the real metabolic activity was half that of the potential. This coincides with cytological observations of Heeger (1990), who attributed the physiological conditions of the protoplasm of Rupertina stabilis during different times of the year to a steady food input. Thus Rupertina stabilis seems to be optimally adapted in its functional morphology and metabolism to a biotope, where particles are carried past it horizontally throughout the year. 
Although on occasions capable of suspension feeding (Fig. 2C) Rhabdammina abyssorum lacks this high degree of morphological adaptation. Measurements of its energy metabolism point to the existence of a different survival strategy. In outlining this it has to be considered that the distinction between these metabolic strategies depend on single samples (Stns P184 \& P185) collected on the same day (13 Feb 1987). Nevertheless large (up to 10-fold) seasonal fluctuations in ATP content and heat production of Rhabdammina abyssorum were determined. ATP turnover rate, however, is maintained at a high, relatively constant value comparable to published values for bacteria (i.e. seconds). Such a rapid turnover allows the foraminifera to take quick advantage of a sudden nutrient input, although this state of readiness is maintained at the cost of the cells' protoplasm, which is consumed during starvation periods. This pattern may indicate a more opportunistic survival strategy of an organism, which lacks the morphological adaptation in an environment that favours suspension feeding.

\section{Vøring Plateau and deep-sea basins}

The dominant foraminifera species on the Voring Plateau, Cribrostomoides subglobosum and Pyrgo rotalaria, feature a survival strategy comparable to that of Rhabdammina abyssorum. The ATP turnover rates of Pyrgo rotalaria are on an even but higher level compared to Rhabdammina abyssorum. In general, the calculated ATP turnover rates of $P$. rotalaria and $C$. subglobosum are in the range known for bacteria. The occurrence of large numbers of intracellular bacteria in $P$. rotalaria suggest the existence of another mode of nutrition (Heeger 1990). Three types of bacteria were observed in the youngest chambers of $P$. rotalaria. The foramineral protoplasm appeared healthy and so the bacteria are probably not parasites. Their abundance, and the occurrence of bacterial secretion products, suggest that the relationship is symbiotic. The bacteria seem to flourish in the favourable microenvironment of the youngest chambers while the foraminifera may gain nourishment, either by assimilating the bacterial metabolic products or by consuming the bacteria themselves (Heeger 1990). Whether the high ATP turnover rates are due to the metabolism of the intracellular bacteria of $P$. rotalaria, their possible symbiotic relationship, or the foraminifera itself cannot be determined at present. These observations, however, combined with the large seasonal fluctuations in ATP content and heat production indicate a life strategy adapted to a seasonally varying food input.
During a study of benthic-pelagic coupling on the Vøring Plateau the response of the benthic community living at $1430 \mathrm{~m}$ depth to a pulse of natural organic matter was monitored (Graf 1989). From 24 May to 4 June 1986, there was a sudden increase in chlorophyll a within the sediment itself, mainly derived from the sedimentation of faecal pellets. The concentrations of ATP in the sediment increased after the pellet pulse and high heat production values were obtained on 24 June. At the end of June 1986 a doubled rate of sediment oxygen consumption was measured at the station (Graf 1989).

Cribrostomoides subglobosum from the Vøring Plateau twice showed increased levels in ATP content above background values. The first in June 1986 at Stn M61 (1245 m) is in agreement with the sedimentation event described above. The second was measured at the same station in August 1988. During this time a massive occurence of heterotrophic pteropods caused a high grazing pressure in the pelagial, which initiated the end of the pelagic summer population (Bathmann et al. 1990). Increased sedimentation was observed by means of drifting sediment traps on 19 August reaching a peak in particle flux of $600 \mathrm{mg}$ dry wt $\mathrm{m}^{-2} \mathrm{~d}^{-1}$ on 22 August 1988. Sediment was sampled at $1245 \mathrm{~m}$ depth on 30 August when it can be assumed that the first particles of this food pulse had just reached the sediment surface. At this time, cytological observations of Heeger (1990) revealed enhanced pseudopodial activity, coccoid algae, copepod remains and dinoflagellates in the food vacuoles of Triloculina sp., Quinqueloculina seminula and Pyrgo rotalaria. Specimens collected at the same site $11 \mathrm{~d}$ before contained only siliceous fragments, occasional algal remains, and a few lipid vesicles. These observations indicate a rapid feeding response to a recent sedimentation event.

In July 1986 a distinct maximum in ATP content, heat production and oxygen consumption of Pyrgo rotalaria from $3276 \mathrm{~m}$ depth was found (Stn M107). At this time of the year the annual maximum in particle flux (270 $\mathrm{mg}$ dry wt $\mathrm{m}^{-2} \mathrm{~d}^{-1}$, in June) was measured in moored sediment traps in the Lofoten Basin $169^{\circ}$ $58.8^{\prime} \mathrm{N}_{;} 00^{\circ} 04.1^{\prime} \mathrm{E}$ at $2950 \mathrm{~m}$ depthj. As on the Vøring Plateau, this maximum was found regularly over a 3 yr period (1986 to 1988) and seems to be the general sedimentation pattern in the Norwegian Sea. The greater water depth explains the time delay of the sedimentation event described above and of a possible reaction of Pyrgo rotalaria.

On the other hand a decompression effect cannot be excluded. Pyrgo rotalaria is the dominant species in the deeper basins of the Norwegian-Greenland Sea (Lutze \& Salomon 1987) and it has to be taken into account that this species might be adapted to 
low temperature and high hydrostatic pressure. The elevated ETS values from the incubation experiments at in situ temperature indicate a possible temperature adaptation of the electron transport chain enzymes. Graf et al. (1988) showed that the heat production of recompressed sediment was a factor of 5 smaller than decompressed sediment, but it remains to be seen if such rates are completely reversible after decompression. The extent of a decompression effect depends on the question whether the enzymes of $P$. rotalaria are pressure adapted or pressure tolerant. The regulation mechanisms of the enzymes and products in the glucose metabolism and the cycling of the adenosine nucleotides are rather complex. Some enzymatic activities (e.g. pyruvate kinase; fructose-1,6-diphosphatase), which are slowed down under high pressure, seem to be counterbalanced by other opposing (therefore activating) effects (Hochachka \& Somero 1980). The potential problems posed by hydrostatic pressure for organisms colonizing the deep-sea (most of these studies were conducted with bacteria and isolates from fish) have been amply identified by studies utilizing hydrostatic pressure as a probe of protein and membrane structure and function (Siebenaller 1987). Hydrostatic pressure is known to affect protein and membrane structure and function, specifically, (1) protein-ligand interactions, (2) rates of catalysis, (3) protein structure stability and (4) membrane lipid fluidity. Further investigations have to be carried out to quantify the effects of decompression and recompression in order to determine whether the high metabolic activities found in foraminifera from greater water depth are real or merely stimulated by decompression

\section{East Greenland Current}

In 1987 investigations in the East Greenland Current were started with the deployment of a moored multiple sediment trap. Due to the arctic origin of the East Greenland Current arctic pelagic communities can be expected. Mechanisms and processes different from those operating on the Vøring Plateau, which is influenced by the Norwegian Atlantic Current and the Norwegian Coastal Current, might lead to the sedimentation of qualitatively different particles. In addition, the seasonal ice covering results in a more stable stratification in the euphotic zone and thus a different sedimentation pattern than on the Vøring Plateau (Smith et al. 1985, Arndt 1990).

In September 1988 a diatom bloom was established at the ice edge, which sedimented at the permanent station (Stn M537) after wind-induced backdrawing of the ice (Hirschleber et al. 1988). Pyrgo rotalaria showed an increase in ATP content and for Cribrostomoides subglobosum the highest ATP and ETS values were measured. In his study Heeger (1990) found at this time the most pronounced reaction in the protoplasm of foraminifera living in East Greenland sediments. The food vacuoles were filled to their capacity with diatoms and dinoflagellates. In contrast to this, newly developed food vacuoles of species from the Vøring Plateau already contained strongly degraded food particles. Whether the metabolic activity of species from East Greenland Current sediments is generally higher than on the Norwegian side cannot be answered at present. The ATP content of Rhabdammina abyssorum showed no significant difference between individuals from the East Greenland and the Norwegian continental margin.

\section{CONCLUSIONS}

This study represents a first attempt to describe the energy metabolism of deep-sea benthic foraminifera and speculates on the ecological significance of the patterns observed. Due to difficulties of sampling at different seasons during the same year in the deepsea, these patterns show many gaps and might have arisen, in part, from interannual rather than seasonal variation. The conclusion, however, that deep-sea benthic foraminifera have apparently developed morphological and physiological adaptations to organic fluxes as well as fluctuations in food supply, is consistent with recent studies based on the more traditional approach of counting dead specimens in preserved samples. Measurements of the energy metabolism combined with live observations of deep-sea benthic foraminifera living in sediments of the NorwegianGreenland Sea reveal indications for 2 different survival strategies.

The suspension feeder Rupertina stabilis is adapted to a hydrographic regime in which it receives a steady input of particles throughout the year, enabling it to maintain a relatively high ATP content by regulating its ATP turnover rate.

In contrast, the sediment surface scavenging Cribrostomoides subglobosum, Pyrgo rotalaria and Rhabdammina abyssorum maintain a high, relatively constant ATP turnover rate. Such a rapid turnover allows these species to take quick advantage of sudden sedimentation events, as encountered on the Voring Plateau and in the East Greenland Current. This state of readiness, however, is maintained by metabolizing their own protoplasm in times of starvation as indicated by high fluctuations in the energy metabolism of the foraminifera. 
Deep-sea foraminifera are ecologically (as well as taxonomically) diverse and include a variety of different feeding-types (Gooday et al. 1992). The survival strategies presented in this study are likely to be applicable to organisms living in environments that experience pronounced seasonality in food input, such as for epibenthic species living in temperate and arctic latitudes. In oligotrophic regions of the ocean, however, where there is little or no seasonality in food supply to the benthos, rhizopod species (such as komokiaceans) may be expected to exhibit different adaptations for survival.

Acknowledgements. The author is grateful to A. N. Antia, A. V Altenbach, S. A. Gerlach, A. J. Gooday, G. Graf and 3 anonymous reviewers for critical reading and improving of the manuscript. The study was supported by the Deutsche Forschungsgemeinschaft and is publication No. 92 of the Sonderforschungsbereich 313, University of Kiel.

\section{LITERATURE CITED}

Alongi, D. M., Pichon, M. (1988). Bathyal meiobenthos of the western Coral Sea: distribution and abundance in relation. to microbial standing stocks and environmental factors Deep Sea Res. 35: 491-503

Altenbach, A. V. (1985). Die Biomasse der benthischen Foraminiferen Auswertung von 'Meteor'-Expedjtionen im östlichen Nordatlantik. Ph.D. thesis, Universität Kiel

Altenbach, A. V. (1987). The measurement of organic carbon in Foraminifera. J. Foram. Res. 17. 106-109

Altenbach, A. V., Sarnthein, M. (1989). Productivity record in benthic foraminifera. In: Berger, W. H., Smetacek, V. S., Wefer, G. (eds.) Productivity of the ocean: present and past, Dahlem Konferenzen, Chichester. Wiley \& Sons Ltd. Bath, p. 255-269

Arndt, K. (1990). Verbreitung, Produktion und Sedimentation von Diatomeen in der Grönlandsee. Diplomarbeit, Universität Kiel

Barnett, P. R. O., Watson, J., Conelly, D. (1984). A multiple corer for taking virtually undisturbed samples from shelf bathyal and abyssal sediments. Oceanol. Acta 7: 399-408

Basov, I. A., Khusid, T A. (1983). Biomass of benthic Foraminifera in sediments of the Sea of Okhotsk. Oceanol. Acad. Sci. U.S.S.R. 23: 489-495

Bathmann, U. V., Peinert, R., Noji, T T., v. Bodungen, B (1990). Pelagic origin and fate of sedimenting particles in the Norwegian Sea. Prog. Oceanogr. 24: 117-125

Bernhard, J M. (1989). The distribution of benthic foraminifera with respect to oxygen concentration and organic carbon levels in shallow-water Antarctic sediments. Limnol. Oceanogr. 34: 1131-1141

Billett, D. S. M., Lampilt, R. S., Rice, A. L., Mantoura, R. F. C (1983). Seasonal sedimentation of phytoplankton to the deep-sea benthos. Nature, Lond. 302: 520-522

Cavalli-Sforza, L. (1972). Biometrie, Grundzüge biologischmedizinischer Statistik. Gustav Fischer Verlag, Stuttgart

Christensen, J. P., Packard, T T (1977). Sediment metabolism from the northwest Afrucan upwelling system. Deep Sea Res. 24: 331-343

Delaca, T E. (1986). Determination of benthic rhizopod biomass using ATP analyses. J Foram. Res. 16: 285-292
Fetter, C. (1973). Recent deep-sea benthic foraminifera from the Alpha Ridge Province of the Arctic Ocean. In Paul, A. Z., Menzies, R. L. (eds.) Benthic ecology of the high arctic deep sea. Rep. Dept. Oceanogr., Florida State University, 297-337

Gage, J. D., Tyler, P. A. (1991). Deep-sea biology: a natural history of organisms at the deep-sea floor. Cambridge University Press, Cambridge

Gnaiger, E. (1980). Das kalorische Äquivalent des ATPUmsatzes im aeroben und anoxischen Metabolismus. Thermochim. Acta 40: 195-223

Gnaiger, E. (1983). Microcalorimetric monitoring of biological activities. Ecological and toxicological studies in aquatic animals. Science Tools 30: 21-26

Gooday, A. J. (1986). Meiofaunal foraminiferans from the bathyal Porcupine Seabight: size structure, taxonomic composition, species diversity and vertical distribution in the sediment. Deep Sea Res. 33: 1345-1373

Gooday, A. J. (1988). A response by benthic Foraminifera to the deposition of phytodetritus in the deep sea. Nature, Lond. 332: 70-73

Gooday, A. J. (1990). Recent deep-sea agglutinated foraminifera: a brief review. In: Hemleben, C., Kaminski, M. A., Kuhnt, W., Scott, D. B. (eds.) Paleoecology, biostratigraphy, paleoceanography and taxonomy of agglutinated foraminifera. NATO ASI Ser., Vol. C327 Kluwer Academic Publishers, Dordrecht, The Netherlands, p. $271-304$

Gooday, A. J., Lambshead, P. J. D. (1989). Influence of seasonally deposited phytodetritus on benthic foraminiferal populations in the bathyal northeast Atlantic: the species response. Mar. Ecol. Prog. Ser. 58: 53-67

Gooday, A. J., Levin, L. A., Linke, P., Heeger, T. (1992). The role of benthic foraminifera in deep-sea food webs and carbon cycling. In: Rowe, G. T., Pariente, V. (eds.) Deepsea food chains and the global carbon cycle. Proceedings NATO ARW, College Station, Texas, April 1991. Kluwer Academic Publishers, Dordrecht, The Netherlands, p. $63-91$

Gooday, A. J., Turley, C. M. (1990). Responses by benthic organisms to inputs of organic material to the ocean floor: a review. Phil. Trans. R. Soc. Lond. A 331: 119-138

Graf, G. (1987). Benthic energy flow during a simulated autumn bloom sedimentation. Mar. Ecol. Prog. Ser. 39: $23-29$

Graf, G. (1989). Benthic-pelagic coupling in a deep-sea benthic community. Nature, Lond 341: 437-439

Graf, G., Bengtsson, W. (1984). Heat production, activity of the electron-transport-system (ETS), the ratio heat production/ETS activity, and ATP-turnover as useful tools in benthic ecological fjeld studies. Arch. Hydrobiol. Beih. Ergeb. Limnol. 19: 249-256

Graf, G., Martens, V., Queisser, W., Weinholz, P., Altenbach, A. (1988). A multicalorimeter for the study of heat production in marine sediments. Mar. Ecol. Prog. Ser. 45: 201-204

Graf, G., Linke, P. (1992). Adensine nucleotides as indicators of deep-sea benthic metabolism. In: Rowe, G. T., Pariente, V. (eds.) Deep-sea food chains and the global carbon cycle. N.4TO ASI Series. Kluwer Academic Publishers, Dordrecht, The Netherlands, p. 237-243

Graf, G., Schulz, R., Peinert, R., Meyer-Reil, L.-A. (1983) Benthic response to sedimentation events during autumn to spring at a shallow-water station in the Western Kiel Bight: I. Analysis of processes on a community level. Mar. Biol. 77: 235-246

Hammen, C. S. (1983). Direct calorimetry of marine invertebrates entering anoxic states. J. exp. Zool. 228: 397-403 
Heeger, T. (1990). Elektronenmikroskopische Untersuchungen zur Ernährungsbiologie benthischer Foraminiferen. Ber. Sonderforschungsbereich 313, Univ. Kiel, No. 21

Henis, Y (1987). Survival and dormancy of microorganisms, Wiley \& Sons, New York

Hessler, R. R. (1974). The structure of deep benthic communities from central oceanic waters. In: Miller, C. B. (ed.) The biology of the oceanic Pacific. Oregon State University Press, Corvallis, p. 79-93

Himms-Hagen, J. (1976). Cellular thermogenesis. Ann. Rev. Physiol. 38: 315-351

Hirschleber, H., Theilen, F., Balzer, W., v. Bodungen, B., Thiede, J. (1988). Forschungsschiff Meteor, Reise 7 vom 1. Juni bis 28. September 1988. Ber. Sonderforschungsbereich 313, Univ. Kiel, No. 10, p. 56-67

Hochachka, P. W. Somero, G. N. (1980). Die grundlegenden Auswirkungen des Druckes auf biologische Systeme. In: Hochachka, P. W., Somero, G. N. (eds.) Strategien biochemischer Anpassung. Thieme Verlag, Stuttgart, p. $294-328$

Ivlev, W. S. (1934). Eine Mikromethode zur Bestimmung des Kaloriengehaltes von Nährstoffen. Biochem. Zeitschrift 275: $51-55$

Kenner, R. A., Ahmed, S. I. (1975). Measurements of electron transport activities in marine phytoplankton. Mar. Biol 33: $119-127$

Köster, M., Jensen, P., Meyer-Reil, L.-A. (1991). Hydrolytic activity asssociated with organisms and biogenic structures in deep-sea sediments from the NorwegianGreenland Sea. In: Christ, R. J. (ed.) Microbial enzymes in aquatic environments. Springer Verlag, Berlin

Linke, P. (1989). Lebendbeobachtungen und Untersuchungen des Energlestoffwechsels benthischer Foraminiferen aus dem Europäischen Nordmeer. Ber Sonderforschungsbereich 313, Univ. Kiel, No. 18

Lochte, K., Turley, C. M. (1988). Bacteria and cyanobacteria assosociated with phytodetritus in the deep sea. Nature, Lond. 333: 67-69

Lutze, G. F., Altenbach. A. V (1988). Rupertina stabilis (Wailich), a highly adapted, suspension feeding foraminifer. Meyniana 40:55-69

Lutze, G. F., Pflaumann, U., Weinholz, P. (1986). Jungquartäre Fluktuationen der benthischen Foraminiferenfaunen in Tiefsee-Sedimenten vor NW-Afrika. Eine Reaktion auf Produktivitätsänderungen im Oberflächenwasser. 'Meteor' Forsch.-Ergebn. C 40: 163-180

Lutze, G. F., Salomon, B. (1987). Foraminiferen-Verbreitung zwischen Norwegen und Grönland: ein West-Ost Profil. Ber. Sonderforschungsbereich 313. Univ. Kiel, No. 6, p. $69-78$

Lutze, G. F., Thiel, H. (1989). Epibenthic foraminifera from elevated microhabitats: Cibicidoides wuellerstorfi and Planulina ariminensis. J. Foram. Res. 19: 153-158

Mackensen, A. (1987). Benthische Foraminiferen auf dem Island-Schottland Rücken. Umweltanzeiger an der Grenze zweier ozeanischer Räume. Palaeontol. Z. 61 . $149-179$

Mackensen, A., Sejrup, H. P., Jansen, E. (1985). The distribution of living benthic foraminifera on the continental slope and rise off Southwest Norway. Mar. Micropaleontol. 9: 275-306

Meyer-Reil, L.-A. (1983). Benthic response to sedimentation events during autumn to spring at a shallow-water station in the Western Kiel Bight: II. Analysis of benthic bacterial populations. Mar. Biol. 77: 247-256

Mever-Reil, L.-A. (1984). Seasonal variations in bacterial biomass and decomposition of particulate organic material

This article was presented by L-A. Meyer-Reil, Kiel, Germany in marine sediments. Arch. Hydrobiol. Beih. Ergeb. Limnol. 19: 201-206

Meyer-Reil, L,-A. (1986). Spatial and temporal distribution of bacterial populations in marine shallow water surface sediments. In: Lassere, P., Martin, J.-P. (eds.) Biogeochemical processes at the land-sea boundary. Elsevier. Amsterdam, p. 141-160

Meyer-Reil, L.-A., Graf, G. (1986). Seasonal development of bacterial communities in a coastal marine sediment as related to the input of organic material. Actes Colloq IFREMER 3: 55-59

Morita, R. Y (1979). Deep-sea microbial energetics. Sarsia 64 $1-12$

Myers, E. H. (1942). A quantitative study of the productivity of the Foraminifera in the sea. Proc. Am. phil. Soc. 85: $325-342$

Nuglisch, K. (1985). Foraminiferen, Neue Brehm-Bücherei, Ziemsen Verlag, Wittenberg

Pamamat, M. M. (1978). Oxygen uptake and heat production in a metabolic conformer (Littorina irrorata) and a metabolic regulator (UCa pugnax). Mar. Biol. 48: 317-325

Rey, F. (1981). Primary production estimates in the Norwegian Coastal Current between $62^{\circ} \mathrm{N}$ and $72^{\circ} \mathrm{N}$. In: Saetre, R., Mork, M. (eds.) The Norwegian Coastal Current, Vol. II. Reklametrykk A. 5., Bergen, p. 640-648

Rumohr, J. (1992). A high accumulation area on the continental slope off northern Norway and sediment transport by cascading winter water. Deep Sea Res. (in press)

Shick, J. M. (1981). Heat production and oxygen uptake in intertidal sea anemones from different shore heights during exposure to air. Mar. Biol. Lett. 2: 225-236

Siebenaller, J. F. (1987). Pressure adaption in deep-sea animals. In: Jannasch, H. W., Marquis, R. E., Zimmermann, A. M. (eds.) Current perspectives in high pressue biology. Academic Press, Harcourt Brace Jovanovich. Publishers, p. 33-48

Smith, K. L., Ir, Clifford, C. H., Eliason, A. H., Walden, B., Rowe, G. T., Teal, J M. (1976). A free vehicle for measuring benthic community metabolism. Limnol. Oceanogr. 21. 164-170

Smith, S. L., Smith, W. O., Codispoti, L. A., Wilson, D. L (1985). Biological observations in the marginal ice zone of the East Greenland Sea. J. mar. Res. 43: 693-717

Snider, L. J., Burnett, B. R., Hessler, R. R. (1984). The composition and distribution of meiofauna and nanobiota in a central North Pacific deep-sea area. Deep Sea Res. 31: $1225-1249$

Tendal, O. S., Hessler, R. R. (1977). An introduction to the biology and systematics of Komokiacea (Textulariina, Foraminiferida). Galathea Reports 14: 165-194

Thiel, H., Pfannkuche, O., Schriever, G., Lochte, K., Gooday, A. J., Hemleben, C., Mantoura, R. F. G., Turley, C. M., Patching, J. W., Riemann, F. (1988/1989). Phytodetritus on the deep-sea floor in a central oceanic region of the Northeast Atlantic. Biol. Oceanogr. 6: 203-239

Thies, A., 1991 Die Benthosforaminiferen im Europäischen Nordmeer Ber. Sonderforschungsbereich 313, Univ. Kiel, No. 31

Tietjen, J. H. (1971). Ecology and distribution of deep-sea meiobenthos off North Carolina. Deep Sea Res. 18 941-957

Turley, C. M., Lochte, K., Patterson, D. J. (1988). A barophilic flagellate isolated from $4500 \mathrm{~m}$ in the mid-North Atlantic. Deep Sea Res. 35: 1079-1092

Witzel, K.-P. (1979). The adenylate energy charge as a measure of microbial activities in aquatic habitats. Arch. Hydrobiol. Beih. Ergeb. Limnol. 12: 146-165 